\title{
Reaction of Stock Price on Dividend Announcements
}

\author{
Angeline Soesanto ${ }^{1}$, Werner R. Murhadi ${ }^{2, *} \&$ Arif Herlambang ${ }^{3}$ \\ ${ }^{1}$ University of Surabaya, Surabaya, Indonesia \\ ${ }^{2}$ University of Surabaya, Surabaya, Indonesia \\ ${ }^{3}$ University of Surabaya, Surabaya, Indonesia \\ "Corresponding author.Email: Werner@staff.ubaya.ac.id
}

\begin{abstract}
This study aims to determine the existence of market reactions that can be seen from the presence of abnormal returns during the dividend announcements in companies listed on the Indonesia Stock Exchange (IDX) during the 2013-2017 period and find out what factors influence the Cumulative Abnormal Return (CAR) when there is a dividend announcement. The research objects were all Indonesian companies listed on IDX that distribute dividends to their shareholders over the 2013-2017 period. The results of this study indicate that the market responds positively to dividend announcements with abnormal returns right on the dividend announcement day when the company distributes higher, lower, and same dividend amounts. While, firm size, founder ownership, firm's age, beta, sales growth, ROA, and dividend yield variables simultaneously have a significant effect on Cumulative Abnormal Return (CAR) during the dividend announcements.
\end{abstract}

Keywords: Abnormal Return, Dividend Announcement, Signaling Theory, Efficient Market Hypothesis, Tax Signaling.

\section{INTRODUCTION}

In determining investments, investors must consider the returns that can be in the form of capital gains and dividends (Nagy \& Obenberger 1994). Investors can also earn more returns from special events such as dividend announcements. The dividend announcement contains information about the company. Based on the Signalling Theory proposed by Ross (1977), an increase in dividends paid gives a clear signal to the market that the company has been progressing. Several studies show that companies making abnormal returns will follow dividend announcements.

Kumar's (2016) research reveals a significant result regarding the abnormal return on the D-1 of dividend announcements when the company distributes higher dividends. This is due to an information leakage from the company that drives investors to act first before the company officially announces dividend distribution. However, Miletic (2011) and Khanal \& Mishra (2017) reveal insignificant results regarding abnormal returns on the D-1 of dividend announcement.

According to Kumar (2016), a significant negative result occurs on the dividend announcement day. This is due to the investor responded negatively to a lower dividend distribution because it is considered a negative company's information. However, Miletic (2011) states an insignificant result on the dividend announcement day; this is because investors do not respond to dividend announcements as they consider that the company does not provide new information to investors. Meanwhile, Khanal \& Mishra (2017) reveal a significant positive result during the dividend announcement day, meaning that investors responded to the dividend announcement positively, as evidenced by an 
abnormal return on the dividend announcement day. Kumar's (2016) research continued by examining the effects of firm size, founder ownership, firm's age, beta, sales growth, ROA, and dividend yield on Cumulative Abnormal Return (CAR). The results show that the firm size and founder ownership variables have a significant negative effect on Cumulative Abnormal Return (CAR), which is due to the larger the firm size, the more information spread in the market. While the founder ownership variable has a significant negative effect because the higher the percentage of the founder's share ownership, the more difficult it is for investors to move the stock price and cause lower abnormal returns.

Based on the results of these findings, it can be seen some significant or insignificant results regarding abnormal returns around the dividend announcements. Therefore, this research will discuss matters related to abnormal returns around the dividend announcements when the company distributes higher, lower, and same dividend amounts and proceed with testing the effects of firm size, founder ownership, firm's age, beta, sales growth, ROA, and dividend yield on Cumulative Abnormal Return (CAR).

\section{RESEARCH METHODS}

This study uses a sample of all companies listed on the Indonesia Stock Exchange that distribute dividends and have an annual report during the study period. This study categorizes the samples into three: (1) companies that distribute higher dividends, (2) companies that distribute lower dividends, and (3) companies that distribute the same dividend amount. The observation time of this study is five days before the dividend announcement, the dividend announcement day itself, and five days after the dividend announcement.

\section{RESULTS AND DISCUSSIONS}

The one-sample t-test in Table 1 shows that a significant positive abnormal return occurs

when tested using Average Abnormal Return (AAR) per day. In addition, significant positive results occurred on the dividend announcement day in 2013-2017 when the company distributed higher dividends. This shows that the market reacted positively by increasing stock prices when the company made a dividend announcement. Investors believe information about the company is given on the dividend announcements, and the information is considered positive because of higher dividend distribution (Kumar 2016).

Table 1. AAR One-Sample T-Test Test Results when the Company Distributes Higher Dividends

\begin{tabular}{ccccccccccc}
\multicolumn{7}{c}{2013} & \multicolumn{10}{c}{2014} & \multicolumn{7}{c}{2015} & \multicolumn{3}{c}{2016} & \multicolumn{2}{c}{2017} \\
& $\mathrm{t}$ & $\mathrm{Sig}$ & $\mathrm{t}$ & $\mathrm{Sig}$. & $\mathrm{t}$ & $\mathrm{Sig}$ & $\mathrm{t}$ & $\mathrm{Sig}$ & $\mathrm{t}$ & $\mathrm{Sig}$ \\
\hline $\mathrm{H}-5$ & -1.2 & 0.2 & 0.5 & 0.5 & -0.4 & 0.6 & 0.4 & 0.6 & 0.8 & 0.3 \\
$\mathrm{H}-4$ & -2.5 & $0.0^{* *}$ & 0.8 & 0.3 & -0.9 & 0.3 & 1.3 & 0.1 & -0.0 & 0.9 \\
$\mathrm{H}-3$ & -0.0 & 0.9 & 0.8 & 0.3 & 0.3 & 0.7 & 1.7 & $0.0^{*}$ & 0.5 & 0.5 \\
$\mathrm{H}-2$ & 0.2 & 0.7 & - & 0.9 & 1.2 & 0.2 & 0.2 & 0.8 & 1.7 & $0.0^{*}$ \\
& & & 0.1 & & & & & & & \\
$\mathrm{H}-1$ & 0.8 & 0.3 & 2.5 & $0.0^{* *}$ & -0.2 & 0.8 & -1.5 & 0.1 & -1.0 & 0.2 \\
$\mathrm{H}-0$ & 5.7 & $0.0^{* *}$ & 4.2 & $0.0^{* * *}$ & 5.0 & $0.0^{* *}$ & 5.7 & $0.0^{* *}$ & 4.1 & $0.0^{* * *}$ \\
& & $*$ & & & & $*$ & & $*$ & & \\
$\mathrm{H}+1$ & -2.5 & $0.0^{* *}$ & 0.1 & 0.9 & -0.4 & 0.6 & -1.0 & 0.2 & -2.7 & $0.0^{* * *}$ \\
$\mathrm{H}+2$ & -0.9 & 0.3 & - & 0.1 & -1.0 & 0.2 & -1.4 & 0.1 & 0.4 & 0.6 \\
& & & 1.6 & & & & & & & \\
$\mathrm{H}+3$ & -0.2 & 0.8 & 0.7 & 0.4 & -1.5 & 0.1 & -0.1 & 0.8 & 0.4 & 0.6 \\
$\mathrm{H}+4$ & -0.5 & 0.6 & 0.6 & 0.5 & -0.8 & 0.4 & -2.0 & $0.0^{* *}$ & -1.1 & 0.2 \\
$\mathrm{H}+5$ & 1.3 & 0.1 & - & 0.7 & -1.3 & 0.1 & 0.9 & 0.3 & -0.6 & 0. \\
& & & 0.3 & & & & & & & 5 \\
\hline
\end{tabular}

Note: $* * *$ Sig at $1 \%, * *$ Sig at $5 \%, *$ sig at $10 \%$

On D-1, D-3, and D-2 of dividend announcements in 2014, 2016, and 2017 respectively, a significant positive result occurred when the company distributed higher dividends.

Table 2. CAR One-Sample T-Test Test Results when the Company Distributes Higher Dividends

\begin{tabular}{|c|c|c|c|c|c|c|c|c|c|c|}
\hline & \multicolumn{2}{|c|}{2013} & \multicolumn{2}{|c|}{2014} & \multicolumn{2}{|c|}{2015} & \multicolumn{2}{|c|}{2016} & \multicolumn{2}{|c|}{2017} \\
\hline & $\mathrm{t}$ & $\mathrm{Si}$ & $\mathrm{t}$ & Sig. & $\mathrm{t}$ & Sig & $\mathrm{t}$ & Sig & $\mathrm{t}$ & Sig \\
\hline & & $\mathrm{g}$ & & & & & & & & \\
\hline-5 to & 0.6 & 0. & 1. & 0.2 & 1.2 & 0.2 & 1.1 & 0.2 & 0.8 & 0.4 \\
\hline+5 & & 5 & 3 & & & & & & & \\
\hline-4 to & 0.6 & 0. & 1. & 0.2 & 1.1 & 0.2 & 0.9 & 0.3 & 0.7 & 0.4 \\
\hline+4 & & 5 & 3 & & & & & & & \\
\hline $\begin{array}{c}-3 \text { to } \\
+3\end{array}$ & 0.8 & $\begin{array}{l}0 . \\
4\end{array}$ & $\begin{array}{l}1 . \\
1\end{array}$ & 0.2 & 1.1 & 0.2 & 1.0 & 0.3 & 0.8 & 0.4 \\
\hline-2 to & 0.8 & 0. & 1. & 0.3 & 1.2 & 0.2 & 0.8 & 0.4 & 0.7 & 0.4 \\
\hline+2 & & 4 & 1 & & & & & & & \\
\hline-1 to & 0.8 & 0. & 1. & 0.3 & 1.0 & 0.3 & 0.9 & 0.4 & 0.5 & 0.6 \\
\hline+1 & & 4 & 2 & & & & & & & \\
\hline-1 to 0 & 1.1 & 0. & 1. & 0.4 & 1.1 & 0.4 & 1.1 & 0.4 & 0.8 & 0.5 \\
\hline & & 4 & 3 & & & & & & & \\
\hline-5 to - & - & 0. & 2. & $0.0^{*}$ & 2.2 & 0.0 & 3.0 & 0.0 & 0.9 & 0.3 \\
\hline 1 & 0.6 & 5 & 1 & & & $*$ & & $*$ & & \\
\hline 0 to & 0.7 & 0. & 1. & 0.4 & 0.9 & 0.5 & 0.8 & 0.5 & 0.5 & 0.6 \\
\hline+1 & & 5 & 0 & & & & & & & \\
\hline+1 to & - & 0. & 0. & 0.7 & - & 0.5 & -1.1 & 0.3 & -1.1 & 0.3 \\
\hline 5 & 0.6 & 5 & 2 & & 0.5 & & & & & \\
\hline
\end{tabular}


This is presumably due to an information leakage from the company that attracts investors to buy many stocks on the day before the dividend announcements, resulting in a stock price on that day (Kumar 2016). This information leakage is supported by the results of Cumulative Abnormal Return in Table 2, which shows a significant positive result also occurs when companies distributed higher dividend in the event window of -5 to -1 in 2014-2016.

On D+1 and D+4 of dividend announcement in 2013 and 2016, it can be seen that the Average Abnormal Return (AAR) is significantly negative; this is due to a late response from the market, which occurs due to investors' lack of experience and information regarding dividend announcements (Felimban et al. 2018).

Table 3. AAR One-Sample T-Test Test Results when the Company Distributes Lower Dividends

\begin{tabular}{ccccccccccc}
\multicolumn{7}{c}{2013} & \multicolumn{7}{c}{2014} & \multicolumn{7}{c}{2015} & & 2016 & 201 \\
& $\mathrm{t}$ & $\mathrm{Sig}$ & $\mathrm{t}$ & $\mathrm{Sig}$. & $\mathrm{t}$ & $\mathrm{Sig}$ & $\mathrm{t}$ & $\mathrm{Sig}$ & $\mathrm{t}$ & $\mathrm{Sig}$ \\
\hline $\mathrm{H}-5$ & -1.9 & $0.0 *$ & 0.6 & 0.5 & 0.8 & 0.4 & -1.2 & 0.2 & -0.1 & 0.8 \\
$\mathrm{H}-4$ & -0.6 & 0.5 & - & 0.3 & 0.2 & 0.7 & -0.8 & 0.4 & 1.6 & $0.0^{*}$ \\
& & & 0.9 & & & & & & & \\
$\mathrm{H}-3$ & -0.7 & 0.4 & - & 0.7 & 0.3 & 0.7 & 1.2 & 0.2 & 0.9 & 0.3 \\
& & & 0.2 & & & & & & & \\
$\mathrm{H}-2$ & -0.5 & 0.5 & 0.4 & 0.6 & 0.5 & 0.5 & -0.0 & 0.9 & -0.3 & 0.7 \\
$\mathrm{H}-1$ & -1.3 & 0.1 & - & 0.2 & -1.1 & 0.2 & 1.0 & 0.2 & 0.4 & 0.6 \\
& & & 1.2 & & & & & & & \\
$\mathrm{H}-0$ & 1.0 & 0.3 & 3.5 & $0.0 * * *$ & 3.1 & $0.0 * *$ & 3.5 & $0.0 * *$ & 1.3 & 0.1 \\
& & & & & & $*$ & & $*$ & & \\
$\mathrm{H}+1$ & -1.0 & 0.2 & - & 0.1 & -0.4 & 0.6 & -2.2 & $0.0 * *$ & -0.3 & 0.7 \\
& & & 1.4 & & & & & & & \\
$\mathrm{H}+2$ & -2.1 & $0.0 * *$ & 0.2 & 0.7 & -2.3 & $0.0 * *$ & 1.7 & $0.0 * *$ & -0.4 & 0.6 \\
$\mathrm{H}+3$ & 0.0 & 0.5 & 0.9 & 0.3 & -1.0 & 0.2 & -1.9 & $0.0 * *$ & 0.7 & 0.4 \\
$\mathrm{H}+4$ & 0.1 & 0.8 & - & 0.7 & -1.4 & 0.1 & -1.8 & $0.0 *$ & 0.5 & 0.5 \\
& & & 0.3 & & & & & & & \\
$\mathrm{H}+5$ & -0.3 & 0.7 & - & 0.2 & 1.1 & 0.2 & 0.9 & 0.3 & -0.3 & 0.7 \\
& & & 1.2 & & & & & & & \\
\hline
\end{tabular}

Note: $* * * \operatorname{Sig}$ at $1 \%, * * \operatorname{Sig}$ at $5 \%, * \operatorname{sig}$ at $10 \%$

From the results of in Table 3 , it can be seen that a significant positive abnormal return occurred in 2014-2016 when the company distributed lower dividends.

AAR and CAR (Table 4) exhibit significant positive results in this study, signifying that the market reacted positively when the company distributed lower dividends. That is because investors believe that the company's profits are still relatively high, so they can still distribute dividends. The results of this study are in line with Pan et al. (2014) results regarding the existence of abnormal returns when the company distributes dividends.
Table 4. CAR One-Sample T-Test Test Results when the Company Distributes Lower Dividends

\begin{tabular}{ccccccccccc}
\hline & 2013 & \multicolumn{3}{c}{2014} & \multicolumn{2}{c}{2015} & 2016 & 2017 \\
& $\mathrm{t}$ & $\mathrm{Si}$ & $\mathrm{t}$ & $\mathrm{Sig}$ & $\mathrm{t}$ & $\mathrm{Sig}$ & $\mathrm{t}$ & $\mathrm{Sig}$ & $\mathrm{t}$ & $\mathrm{Sig}$ \\
& & $\mathrm{g}$ & &. & & & & & & \\
\hline-5 to & 0.2 & 0. & 0.4 & 0.6 & 0.5 & 0.5 & 1. & 0.2 & -0.1 & 0.8 \\
+5 & & 8 & & & & & 3 & & & \\
-4 to & 0.5 & 0. & 0.4 & 0.6 & 0.4 & 0.6 & 1. & 0.2 & 0.3 & 0.7 \\
+4 & & 5 & & & & & 3 & & & \\
-3 to & 0.4 & 0. & 0.3 & 0.7 & 0.7 & 0.4 & 1. & 0.1 & 0.9 & 0.3 \\
+3 & & 6 & & & & & 9 & & & \\
-2 to & 0.4 & 0. & 0.4 & 0.6 & 0.8 & 0.4 & 1. & 0.2 & 1.7 & 0.1 \\
+2 & & 6 & & & & & 4 & & & \\
-1 to & 0.6 & 0. & 0.4 & 0.7 & 0.8 & 0.4 & 1. & 0.4 & 0.8 & 0.4 \\
+1 & & 5 & & & & & 0 & & & \\
-1 to 0 & 0.7 & 0. & 0.7 & 0.5 & 0.8 & 0.5 & 1. & 0.4 & 0.2 & 0.8 \\
& & 5 & & & & & 2 & & & \\
-5 to - & -1.1 & 0. & - & 0.6 & - & 0.3 & 0. & 0.4 & 0.0 & 0.9 \\
1 & & 5 & 0. & & 0.9 & & 8 & & & \\
& & & 5 & & & & & & & \\
0 to & 0.8 & 0. & 0.5 & 0.7 & 0.9 & 0.5 & 0. & 0.5 & 9.6 & 0.0 \\
+1 & & 5 & & & & & 8 & & & $*$ \\
+1 to & -1.3 & 0. & - & 0.3 & - & 0.3 & 0. & 0.8 & -0.8 & 0.4 \\
5 & & 2 & 1. & & 0.9 & & 2 & & & \\
\hline
\end{tabular}

Note: $* * * \operatorname{Sig}$ at $1 \%, * * \operatorname{Sig}$ at $5 \%, *$ sig at $10 \%$

Table 5 exhibits that when a company distributes the same dividend amount, a significant positive result occurs. It signifies a positive market response on the dividend announcement day when the company distributes the same dividend.

Table 5. AAR One-Sample T-Test Test Results when the Company Distributes same Dividends

\begin{tabular}{ccccccccccc}
\multicolumn{1}{c}{2013} & \multicolumn{1}{c}{2014} & \multicolumn{2}{c}{2015} & \multicolumn{2}{c}{2016} & \multicolumn{2}{c}{2017} \\
& $\mathrm{t}$ & $\mathrm{Sig}$ & $\mathrm{t}$ & $\mathrm{Sig}$. & $\mathrm{t}$ & $\mathrm{Sig}$ & $\mathrm{t}$ & $\mathrm{Sig}$ & $\mathrm{t}$ & $\mathrm{Sig}$ \\
\hline $\mathrm{H}-5$ & -0.6 & 0.5 & 1.6 & 0.1 & -1.0 & 0.3 & 0.1 & 0.8 & -1.1 & 0.2 \\
$\mathrm{H}-4$ & -0.5 & 0.5 & 2.3 & $0.0^{* *}$ & 1.5 & 0.1 & 0.3 & 0.7 & -1.8 & $0.0^{*}$ \\
$\mathrm{H}-3$ & 0.3 & 0.7 & - & 0.1 & 1.4 & 0.1 & 1.4 & 0.1 & 1.6 & 0.1 \\
& & & 1.6 & & & & & & & \\
$\mathrm{H}-2$ & 0.1 & 0.9 & - & 0.4 & 0.4 & 0.6 & 1.4 & 0.1 & -0.4 & 0.6 \\
& & & 0.6 & & & & & & & \\
$\mathrm{H}-1$ & 0.6 & 0.5 & 0.1 & 0.8 & 0.9 & 0.3 & -0.8 & 0.3 & -0.2 & 0.7 \\
$\mathrm{H}-0$ & 2.4 & $0.0^{* *}$ & 2.7 & $0.0^{* *}$ & 1.8 & $0.0^{*}$ & 1.7 & $0.0^{*}$ & 1.2 & 0.2 \\
$\mathrm{H}+1$ & -0.2 & 0.8 & - & 0.3 & 0.8 & 0.3 & -0.1 & 0.8 & -0.7 & 0.4 \\
& & & 0.9 & & & & & & & \\
$\mathrm{H}+2$ & -2.2 & $0.0^{* *}$ & - & 0.9 & -0.8 & 0.3 & -0.7 & 0.4 & 0.2 & 0.7 \\
& & & 0.0 & & & & & & & \\
$\mathrm{H}+3$ & -0.7 & 0.4 & 0.3 & 0.7 & -0.1 & 0.8 & -0.8 & 0.3 & -0.6 & 0.5 \\
$\mathrm{H}+4$ & 0.5 & 0.6 & 0.9 & 0.3 & 0.9 & 0.3 & 1.0 & 0.3 & -0.4 & 0.6 \\
$\mathrm{H}+5$ & -0.9 & 0. & - & 0.6 & 0.9 & 0.3 & -0.6 & 0.4 & -0.4 & 0.6 \\
& & 3 & 0.4 & & & & & & & \\
\hline
\end{tabular}

Note: $* * * \operatorname{Sig}$ at $1 \%, * * \operatorname{Sig}$ at $5 \%, *$ sig at $10 \%$

As previously mentioned, the positive reaction occurs because investors feel more optimistic if companies can distribute dividends, regardless of higher, lower, or same amount than companies that cannot distribute dividends at all (Pan et al. 2018).

A positive response when the company distributes the same dividends is strengthened by the results of the significance of the Cumulative Abnormal Return in Table 5. Where, the event window of -5 to $+5,-4$ to $+4,-5$ to -1 in 
$2014,-5$ to $+5,-4$ to $+4,-3$ to $+3,-1$ to $+1,-1$ to 0 in 2016, and -1 to 0 in 2017 show significant positive results.

Table 6. CAR One-Sample T-Test Test Results when the Company Distributes same Dividends

\begin{tabular}{|c|c|c|c|c|c|c|c|c|c|c|}
\hline & \multicolumn{2}{|c|}{2013} & \multicolumn{3}{|c|}{2014} & 2015 & \multicolumn{2}{|c|}{2016} & \multicolumn{2}{|c|}{2017} \\
\hline & $\mathrm{t}$ & Sig & $\mathrm{t}$ & Sig. & $\mathrm{t}$ & Sig & $\mathrm{t}$ & Sig & $\mathrm{t}$ & Sig \\
\hline $\begin{array}{c}-5 \text { to } \\
+5\end{array}$ & -0.2 & 0.8 & 2.2 & $0.0^{* * *}$ & 2.8 & $0.0^{* *}$ & 0.9 & 0.3 & 0.4 & 0.6 \\
\hline $\begin{array}{l}-4 \text { to } \\
+4\end{array}$ & 0.3 & 0.7 & 2.1 & $0.0^{*}$ & 2.6 & $0.0^{* *}$ & 1.0 & 0.3 & 0.4 & 0.6 \\
\hline $\begin{array}{c}-3 \text { to } \\
+3\end{array}$ & 0.2 & 0.7 & 1.4 & 0.1 & 2.8 & $0.0^{* *}$ & 0.8 & 0.4 & 0.7 & 0.4 \\
\hline $\begin{array}{c}-2 \text { to } \\
+2\end{array}$ & 0.3 & 0.7 & 1.0 & 0.3 & 2.0 & 0.1 & 0.5 & 0.5 & 0.3 & 0.7 \\
\hline $\begin{array}{c}-1 \text { to } \\
+1\end{array}$ & 1.3 & 0.2 & 1.1 & 0.3 & 4.1 & $0.0^{*}$ & 0.5 & 0.6 & 0.9 & 0.4 \\
\hline-1 to 0 & 2.1 & 0.2 & 4.0 & 0.1 & 6.5 & $0.0^{*}$ & 0.5 & 0.6 & 8.0 & $0.0^{*}$ \\
\hline $\begin{array}{c}-5 \text { to }- \\
1\end{array}$ & -0.1 & 0.8 & 2.7 & $0.0^{* *}$ & 1.6 & 0.1 & 0.8 & 0.4 & 0.2 & 0.8 \\
\hline $\begin{array}{c}0 \text { to } \\
+1\end{array}$ & 0.8 & 0.5 & 0.5 & 0.6 & 2.3 & 0.2 & 0.9 & 0.5 & 0.3 & 0.8 \\
\hline $\begin{array}{c}+1 \text { to } \\
5\end{array}$ & -1.2 & 0.2 & -0.1 & 0.8 & 1.9 & 0.1 & -1.4 & 0.2 & -0.3 & 0.7 \\
\hline
\end{tabular}

Note: $* * * \operatorname{Sig}$ at $1 \%, * * \mathrm{Sig}$ at $5 \%, *$ sig at $10 \%$

In Table 6, it can be seen that the greater the testing of the event window, the lower the level of significance; this is due to the highest level of stock returns on the dividend announcement day so that when the event window is widened, the level of significance decreases (Kumar 2016).

Table 7. Regression Test Results

\begin{tabular}{lccc}
\hline \multicolumn{1}{c}{ Variable } & Coef. & Stat. & Prob. \\
\hline C & 0.218 & 5.968 & 0.000 \\
SIZE & & & $0.002^{* *}$ \\
FOUND- & -0.005 & -2.996 & $*$ \\
ER_OWNERSHIP & 0.204 & 7.324 & $* .000^{* *}$ \\
& & & $0.000^{* *}$ \\
AGE & -0.002 & -4.304 & $*$ \\
BETA & -0.007 & -1.149 & 0.251 \\
& & & $0.000^{* *}$ \\
GROWTH & -0.045 & -5.027 & $*$ \\
ROA & -0.074 & -2.133 & $0.033^{* *}$ \\
DY & -0.007 & -1.185 & 0.236 \\
R-squared & 0.505 & & \\
Adjusted R-squared & 0.373 & & \\
S.E. of regression & 0.082 & & \\
F-statistic & 3.827 & & \\
Prob(F-statistic) & $0.000^{* * *}$ & & \\
\hline
\end{tabular}

Note: $* * *$ Sig at $1 \%, * *$ Sig at $5 \%, *$ sig at $10 \%$

Based on the results in Table 7 by conducting a T-test, it can be seen that the variables of firm size, founder ownership, firm's age, sales growth, and ROA significantly influence the Cumulative Abnormal Return (CAR). In contrast, Beta and dividend yield variables insig- nificantly influence the Cumulative Abnormal Return (CAR).

Based on the test results using the $\mathrm{F}$ test, the results of statistical calculations show Fstatistics $=3.827823$ with a probability of $0.000000<0.05$. It means that firm size, founder ownership, firm's age, beta, sales growth, ROA, and dividend yield variables have a significant effect on Cumulative Abnormal Return (CAR). From the regression test results, it can be seen that the firm size variable has a significant negative effect on Cumulative Abnormal Return (CAR). It is because the larger the firm size, the more information spread in the market; thus, the dividend announcement is a new source of information (Amihud \& Li 2016, Kumar 2016).

The founder ownership variable has a significant positive effect on Cumulative $\mathrm{Ab}$ normal Return (CAR) at a significance level of $1 \%$. This is due to the higher the share ownership by the founder, the more the company's performance is supervised, and it leads to higher investor confidence in the company so that more investors are buying company stocks and causing stock prices to increase (Eugster 2014).

The firm's age variable has a significant negative effect on Cumulative Abnormal Return (CAR) at a significance level of $1 \%$. This is because the higher the firm age, the more information about the company spread in the market. As a result, dividend announcements are no longer a new source of information for investors (Amihud \& Li 2006).

The beta variable has no significant negative effect on Cumulative Abnormal Return (CAR). It is because the higher beta indicates the higher market risk, which will automatically increase the risk of company stocks. As a result, not all investors dare to invest their funds in stocks so that there is no reaction to stock prices (Kumar 2016, Siahaan 2009).

The sales growth variable has a significant negative effect on Cumulative Abnormal Return (CAR) at a significance level of $1 \%$. It is because the higher the company's sales growth, the higher the operational costs to finance its operations. As such, companies pre- 
fer to reduce their dividend payments, resulting in a perceived decline in the company's performance by investors (Lau et al. 2002).

The ROA variable has a significant negative effect on Cumulative Abnormal Return (CAR) at a significance level of $1 \%$. It is because the returns earned from capital gains are higher than the returns earned during dividend announcements. Thus, investors tend to choose to sell their share ownership when they find out the company will make a dividend announcement to avoid taxes upon receiving dividends and decide to buy other stocks with high ROA that do not distribute dividends (Arko et al. 2014, Halim 2015).

The dividend yield variable has no significant negative effect on Cumulative Abnormal Return (CAR). It is because investors tend to prefer the distribution of profits in the form of capital gains compared to dividends. Thus, regardless of whether the company distributes dividends or not, it will not affect investors' decisions in investing (Kumar 2016, Halim 2015).

The coefficient of determination used is adjusted R2 with a value of 0.373 . This coefficient means that the change in the variable of Cumulative Abnormal Return (CAR) can be explained quite well by firm size, founder ownership, firm's age, beta, growth, ROA, and dividend yield by $37.34 \%$, while the rest is $62.66 \%$ is explained by other variables not included in this study.

\section{CONCLUSION}

The results conducted using the one-sample ttest show a significant positive investor reaction on the dividend announcement day when the company distributes higher, lower, and same dividends. Moreover, this also signifies that the understanding of investors in Indonesia regarding information content during the dividend announcement is still not evenly distributed. This is demonstrated from significant results on the day before and after the dividend announcement.

Based on the results of hypothesis testing, it can be seen that firm size, founder ownership, firm's age, sales growth, and ROA variables have a significant effect on Cumulative Ab- normal Return (CAR). In contrast, the Beta and dividend yield variables insignificantly influence Cumulative Abnormal Return (CAR).

This study has limitations: it would be better to examine the difference in abnormal returns using the paired sample t-test to compare significant unusual return differences before and after the dividend announcement. Besides, researchers can also include other factors that might affect the Cumulative Abnormal Return (CAR) when a company makes a dividend announcement.

\section{REFERENCES}

Arko, A.C, Abor, J., Adjasi, C.K.D., \& Amidu, M. 2014. What influence dividend decisions of firms in Sub-Saharan African?. Journal of Accounting in Emerging Economies 4(1): 57-78.

Amihud, Y. \& Li, K. 2016. The Declining Information Content of Dividend Announcements and the Effects of Institutional Holdings, Journal of Financial and Quantitative Analysis 41(3):637-660

Eugster, N. 2014. Ownership Structure and Stock Return: Analysis of the Impact of Family Shareholding. Proceedings. The $27^{\text {th }}$ Australasian Finance and Banking Conference.

Felimban, R., Floros. C. \& Nguyen, A.N. 2018. The Impact of Dividend Announcements on Share Price and Trading Volume: Empirical Evidence from the Gulf Cooperation Council (GCC) Countries, Journal of Economic Studies 45(2):210-230.

Halim, A. 2015. Manajemen Keuangan Bisnis Konsep dan Aplikasinya. (Edisi Pertama). Jakarta: Mitra Wacana Media.

Khanal, A.R. \& Mishra, A.K. 2017. Stock Price Reactions to Stock Dividend Announcements: A Case from a Sluggish Economic Period. North American Journal of Economics and Finance 42: 338-345.

Kumar, S. 2017. New Evidence on Stock Market Reaction to Dividend Announcement in India. Research in International Business and Finance 39A: 327337.

Lau, S.T., Lee, C.T. \& Mc.Inish, T.H. 2002. Stock Returns and Beta, Firms Size, E/P, CF/P, Book-toMarket, and Sales Growth: Evidence from Singapore and Malaysia. Journal of Multinational Financial Management 12:207-222.

Miletic, M. 2011. Stock Price Reaction to Dividend Announcement in Croatia. Economic ResearchEkonomska Istrazivanja 24(3): 147-156.

Nagy, R.A. \& Obenberger, R.W. 1994. Factors Influencing Individual Investor Behaviour. Financial Analysts Journal. 50(4): 63-68.

Ross, S.A. 1977. The Determination of Financial Structure: The Incentive Signaling Approach. Journal of Economics 8 (1): 23-40. 